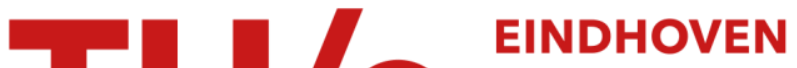 \\ UNIVERSITY OF \\ TECHNOLOGY
}

\section{Melting behaviour of gelspun/drawn polyolefins}

\section{Citation for published version (APA):}

Bastiaansen, C. W. M., \& Lemstra, P. J. (1989). Melting behaviour of gelspun/drawn polyolefins.

Makromolekulare Chemie, Macromolecular Symposia, 28, 73-84. https://doi.org/10.1002/masy.19890280107

DOI:

10.1002/masy.19890280107

Document status and date:

Published: 01/01/1989

\section{Document Version:}

Publisher's PDF, also known as Version of Record (includes final page, issue and volume numbers)

\section{Please check the document version of this publication:}

- A submitted manuscript is the version of the article upon submission and before peer-review. There can be important differences between the submitted version and the official published version of record. People interested in the research are advised to contact the author for the final version of the publication, or visit the $\mathrm{DOI}$ to the publisher's website.

- The final author version and the galley proof are versions of the publication after peer review.

- The final published version features the final layout of the paper including the volume, issue and page numbers.

Link to publication

\section{General rights}

Copyright and moral rights for the publications made accessible in the public portal are retained by the authors and/or other copyright owners and it is a condition of accessing publications that users recognise and abide by the legal requirements associated with these rights.

- Users may download and print one copy of any publication from the public portal for the purpose of private study or research.

- You may not further distribute the material or use it for any profit-making activity or commercial gain

- You may freely distribute the URL identifying the publication in the public portal.

If the publication is distributed under the terms of Article $25 \mathrm{fa}$ of the Dutch Copyright Act, indicated by the "Taverne" license above, please follow below link for the End User Agreement:

www.tue.nl/taverne

Take down policy

If you believe that this document breaches copyright please contact us at:

openaccess@tue.nl

providing details and we will investigate your claim. 
MELTING BHHAVIOUR OF GELSPUN/DRAWN POLYOLEEINS

C.W.M. Bastiaansen ${ }^{I}$ and P.J. Lemstra ${ }^{2 *}$

1) DSM Research and Eatents, P.0. Box 18, $6160 \mathrm{MD}$ Geleen, The Netherlands

2) Eindhoven University of Technology, Department of Polymer

Technology, P.0. Box 513, $5600 \mathrm{MB}$ Eindhoven, The Netherlands

Abstract: The melting behaviour of gelspun/drawn UHMW-PE and UHMW-PP fibres was investigated. Unconstrained UHMW-PE and UHMW-PP fibres melt at $142^{\circ} \mathrm{C}$ and $170^{\circ} \mathrm{C}$, respectively. Upon constraining, by holding the fibres at a fixed length or by embedding the fibres in a matrix, an increase in the melting temperature of both fibres is observed. In the case of UinW-PE fibres a solid-solid phase transition in polyethylene at $155^{\circ} \mathrm{C}$ from the orthorombic to the hexagonal crystal structure occurs. Above $155^{\circ} \mathrm{C}$, the fibres can not sustain any load. This solid-solid phase transition at $155^{\circ} \mathrm{C}$ sets an upper limit to both the maximum curing and continuous use temperature of $\mathrm{PE}-\mathrm{f} i b r e$ reinforced composites. In gelspun/drawn UIMW-PP, such a detrimental solid-solid phase transition is absent, and therefore the increase in melting temperature can be utilized effectively. For example, heating of UHMW-PP fibres for 30 minutes at $200^{\circ} \mathrm{C}$ does hardly affect the room temperature Young's modulus and tensile strength if the fibre is constrained during heating.

\section{INTRODUCTION}

In the past decade a large effort has been made to bridge the gap between the strength and stiffness of polyolefins crystallized from an isotropic melt or solution and the theoretical strength and stiffness of linear. infinitely long, chain-extended polyolefin structures (Ref. 1-3). The prime objective of these efforts was to exploit the intrinsic high strength and modulus of polyolefines by generating chain-extension/ alignnent. Recently processes have been developed for the production of high-strength and high-modulus polyolefin fibres such as melt-spinning/ drawing and solution (ge1)-spinning/drawing (Ref. 4,5). In the gelspinning process a semi-dilute solution of an Ultra-High-MolecularWeight polyolefin is spun and after quenching/crystallization drawn in 
the solid state to extend and align the macromolecules. UHM-PE fibres are currently produced with a Young's modulus and tensile strength of respectively $100-150 \mathrm{GPa}$ and $3-4 \mathrm{GPa}$. In the case of UHMW-PP the maximum achievable Young's modulus and tensile strength found were respectively $40 \mathrm{GPa}$ and $1.5 \mathrm{GPa}(\operatorname{Ref}, 6,7)$.

The melting behaviour of drawn polyolefin fibres is rather complex (Ref. 8). Various melting endotherms can be observed which are difficult to interpret (Ref. 9). Previous studies on the melting behaviour of gelspun/ drawn polyethylene indicated that the various melting endotherms originated from the sample preparation methods used (Ref. 12,13). An additional comparative study was performed on the melting behaviour of both UHMW-PE and UHMW-PP gelspun/drawn structures. Special attention is devoted in this study to the influence of constraining on the melting behaviour of these fibres in view of their possible application in composites.

\section{EXPERIMENTAL}

UHMW-PE fibres were supplied by Dyneema Vof, a joint venture of DSM and Toyobo. The multifilament fibre possessed a Young's modulus of 110 GPa and a tensile strength of $3.2 \mathrm{GPa}$.

The UHMW-PP grade used in this study $\left(M_{\mathrm{w}} \sim 2 * 10^{3} \mathrm{~kg}\right.$ mol-1) was supplied by Himont (USA). UHMW-PP fibres were spun/drawn possessing a Young's modulus of $35 \mathrm{GPa}$ and a tensile strength of $1.5 \mathrm{GPa}$.

The Young's modulus and tensile strength of the fibres at room temperature were measured using a Zwick tensile tester at a strain rate of $0.01 \mathrm{~s}^{-1}$. Corona discharge was employed to improve adhesion of the $\mathrm{PE}$ and $P P$ fibres to the epoxy matrix.

Shrinkage measurements were performed in an thermostatically controlled oven. A standard heating rate of $5^{\circ} \mathrm{C} / \mathrm{min}$ was used. In these measurements the fibres were allowed to shrink freely, and the change in length of the fibres was measured.

Retractive force measurements were performed in an oven equipped with a load cell. During the measurements the fibres were held at a fixed length, and a standard heating rate of $5^{\circ} \mathrm{C} / \mathrm{min}$ was used. 
DSC-curves were recorded on a Perkin-Elmer DSC-2. A standard heating rate of $5^{\circ} \mathrm{C} / \mathrm{min}$ was used. To investigate the influence of constraining on the melting behaviour of fibres, different sample preparation methods were used:

a. Unconstrained melting

In unconstrained DSC-experiments, chopped fibres, length 1-2 $\mathrm{mm}$, were used, and a few droplets of silicon-oil were added to the DSC-pans to improve heat contact and to allow friction-free shrinkage upon meiting.

b. Constrained melting

Corona-treated fibres were embedded in epoxy and/or polyester resins to constrain the fibres. Prior to the DSC-measurements the epoxy resin was cured for 12 hours at $120^{\circ} \mathrm{C}$. In the case of UMMW-PE a few DSC-experiments were performed on chain-extended fibres wound tightly around a thin wire to which the ends of the fibre were knotted.

Annealing experiments on UHM-PP fibres were performed in a thermostatically controlled silicon-oil bath. During the annealing experiments the fibres were held at a fixed length. After annealing, the fibres were washed with acetone to remove residual traces of silicon-oil. High temperature WAXS patterns were recorded of fibres held at a fixed length using a Statton camera. Ni-filtered $\mathrm{Cu}-\mathrm{K} \alpha$ radiation was used and generated at $40 \mathrm{kV} / 25 \mathrm{~mA}$. The sample to film distance was $40 \mathrm{~mm}$.

RESULTS AND DISCUSSION

氧

\section{A. UNCONSTRAINED MELTING OF PE AND PP FIBRES}

In Figure la and ib shrinkage measurements are shown of respectively UHMW-PE and UIMW-PP fibres. In these measurements the shrinkage is defined as the relative change in sample length, $\Delta 1 / 1_{0} * 100 \%$; $1_{0}$ being the initial sample length at room temperature. As can be inferred from these figures, the UHMW-PE and UHMW-PP fibres melt. and shrink approximately $96 \%$ in a narrow temperature range around respectively $142^{\circ} \mathrm{C}$ and $170^{\circ} \mathrm{C}$. The high values for the total shrinkage indicate that the UHMW-PE and UHMW-PP fibres indeed consist of highly extended macromolecules (Ref. 9) which recoil upon melting. 
$\underline{a}$

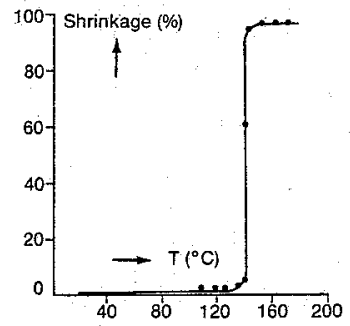

$\underline{\mathrm{b}}$

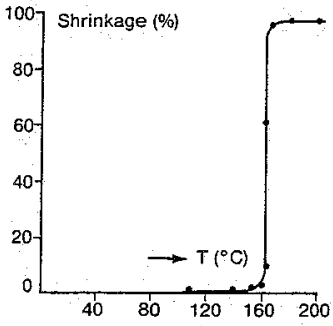

Figure 1. Shrinkage measurements of:
a. UHMW-PE fibres

b. INMW-PP fibres

$\underline{a}$

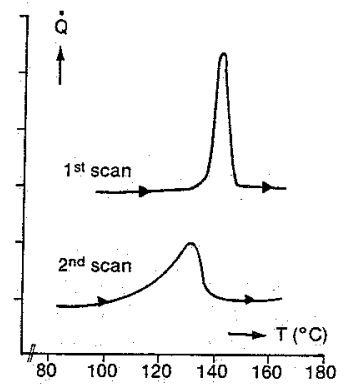

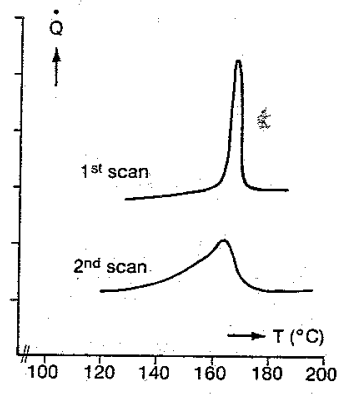

Figure 2. DSC experiments of unconstrained fibres

a. UHMW-PE fibres

b. UHMW-PP fibres 
In Figure 2a and 2b DSC-measurements are shown of chopped UWMW-PE and UHMW-PP fibres suspended in silicon-oil. In the first scan single melting endotherms are observed at respectively $142^{\circ} \mathrm{C}$ and $171{ }^{\circ} \mathrm{C}$, (peak values), which is close to the melting temperatures estimated from the shrinkage measurements. The melting temperature, heat of fusion and crystallinity of both the UHMW-PE and UHMW-PP fibres are listed in Table 1.

\begin{tabular}{lllllll}
\hline & $\begin{array}{c}\mathrm{T}_{\mathrm{m}_{1}} \\
\left({ }^{\circ} \mathrm{C}\right)\end{array}$ & $\begin{array}{c}\Delta \mathrm{H}_{1} \\
(\mathrm{~J} / \mathrm{g})\end{array}$ & $\begin{array}{c}\text { cryst. } \\
(\%)\end{array}$ & $\begin{array}{c}\mathrm{T}_{\mathrm{m}_{2}} \\
\left({ }^{\circ} \mathrm{C}\right)\end{array}$ & $\begin{array}{c}\Delta \mathrm{H}_{2} \\
(\mathrm{~J} / \mathrm{g})\end{array}$ & $\begin{array}{c}\text { cryst. } \\
(\%)\end{array}$ \\
\hline $\mathrm{PE}$ & 142 & 239 & 81 & 133 & 122 & 42 \\
$\mathrm{PP}$ & 171 & 122 & 73 & 163 & 65 & 38 \\
\hline
\end{tabular}

Table 1. Melting temperature, heat of fusion and crystallinity of unconstrained UHMW-PE and UHMW-PP fibres

The crystallinity was calculated assuming a heat of fusion of crystalline polyethylene and polypropylene of respectiveiy $293 \mathrm{~kJ} / \mathrm{kg}$ and $165 \mathrm{~kJ} / \mathrm{kg}$. Upon quenching and re-scanning, again single melting endotherms are observed (Figures $2 \mathrm{a}$ and $2 \mathrm{~b}$ ). The melting temperature, heat of fusion and crystallinity of both fibres have decreased indicating that the original chain-extended morphology of the fibres is completely lost after the first scan in the DSC experiments.

:

\section{B. CONSTRAINED MELTING OF UTMN-PE FIBRES}

In Figure 3 retractive force measurements of UHMW-PE fibres held at a fixed length are shown. As can be inferred from this figure, stress builds up in the fibre during heating to a maximum of approximately 50 $\mathrm{MPa}$ and the fibre fractures at $152^{\circ} \mathrm{C}$. The temperature at which the fibres fracture is relatively high (compare with figure la and $2 a$ ), which indicates that the constraining during the retractive force measurements influences the melting behaviour of the UHMW-PE fibres. In a previous study (Ref. 9) on the melting behaviour of UHMW-PE fibres, several melting endotherms could be observed during heating in the DSC, Figure 4 . 


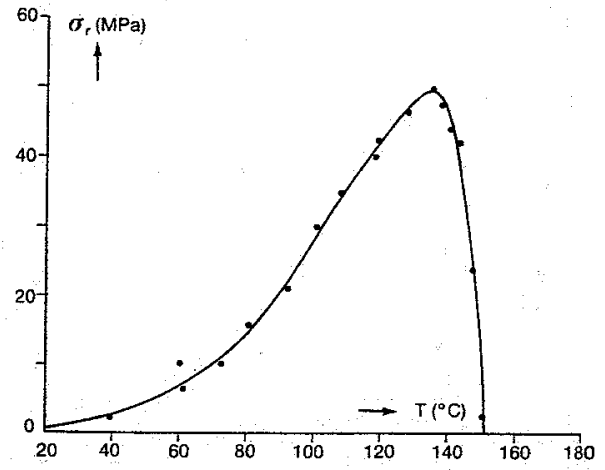

Figure 3. Retractive force measurements of UHMW-PE fibres

In these experiments, UMM-PE fibres were wound tightly around a wire with knotted ends. However, if constrained properly, only one endotherm is observed (Ref. 12,13). Figure 5 shows the melting behaviour of UHMW-PE fibres embedded in an epoxy matrix. Compared to figure $2 a$, the melting endotherm shifts to $155^{\circ} \mathrm{C}$. Upong melting and rescanning, several melting endotherms are observed indicative of some memory of the original chain-extended morphology of the UHMW-PE fibres.

The endotherm at $155^{\circ} \mathrm{C}$ in the first scan of UHMW-PE fibres embedded in a matrix material is comnonly associated with a solid-solid phase transition from an orthorombic to a hexagonal crystal structure (Ref. $8,9,11,12)$. Characteristic for this hexagonal or rotator phase of polyethylene is the high mobility of macromolecules within the crystal lattice (Ref. 10). In retractive force measurements this increase in mobility allows macromolecules to slip past each other and recoil, thus causing the failure of the fibres. 


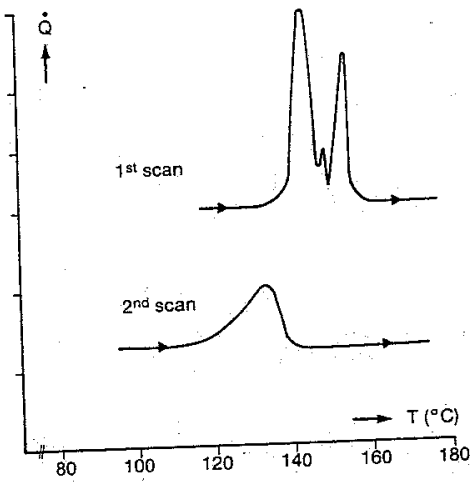

Figure 4. DSC-experiments of UHMW-PE fibres wound around a thin wire

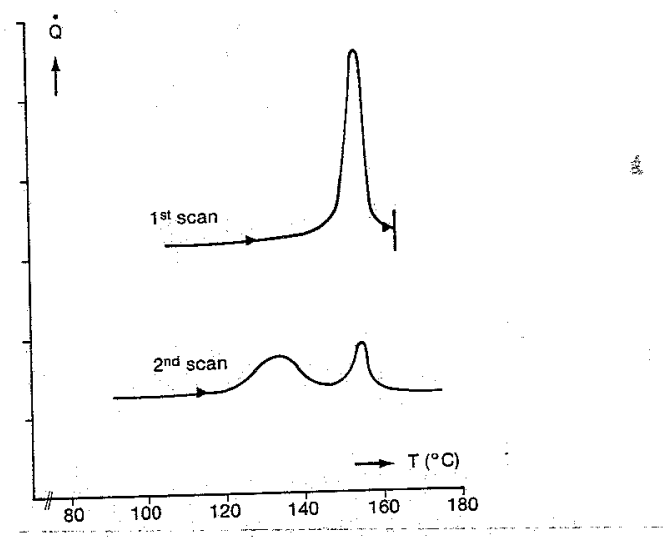

Figure 5. DSC-experiments of constrained UEMW-PE fibres 
The hexagonal phase observed in embedded UHMW-PE fibres at temperatures above $155^{\circ} \mathrm{C}$ should yield a melting endotherm upon heating to higher temperatures. These melting endotherms are indeed experimentally observed, but a large scatter in peak temperatures depending on the embedding matrix causes problems to define a proper melting temperature. In Figure 6 shrinkage and retractive force measurements on an unidirectional UHMW-PE reinforced composite material are shown (matrix material: epoxy resin, fibre to epoxy ratio $=1: 1$ ). From this figure it is clear that during both fabrication and practical use the temperature of the composite material should never exceed $155^{\circ} \mathrm{C}$ since this will result in fracture, shrinkage and loss in Young's modulus and tensile strength of the composite.

C. CONSTRAINED MELTING OF UHMW-PP FIBRES

In Figure 7 retractive force measurements are shown of UHMW-PP fibres. These measurements show that UHMW-PP fibres, if held at a fixed length, fracture at temperatures well above $200^{\circ} \mathrm{C}$.

In DSC-experiments on UHMW-PP fibres embedded in a suitable matrix material, the first significant melting endotherm appears at approximately $220^{\circ} \mathrm{C}$. These experiments show that there is a substantial gap between the melting temperature of UHWW-PP fibres which are allowed to shrink freely and the melting temperature of UHMW-PP fibres held at a fixed length (compare figure 8 and figure $2 \mathrm{~b}$ ). After quenching and re-scanning a single melting endotherm is observed indicating that the UMM-PP melt was completely randomized in the first scan after heating to $260^{\circ} \mathrm{C}$.
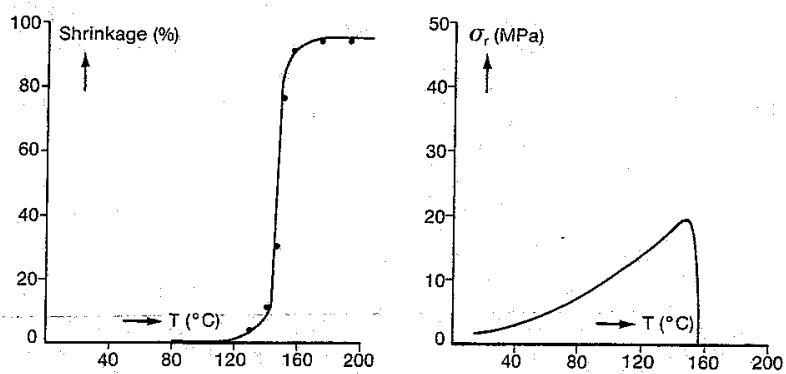

Figure 6. Shrinkage and retractive force measurements of an unidirectional UHMW-PE fibre reinforced composite 


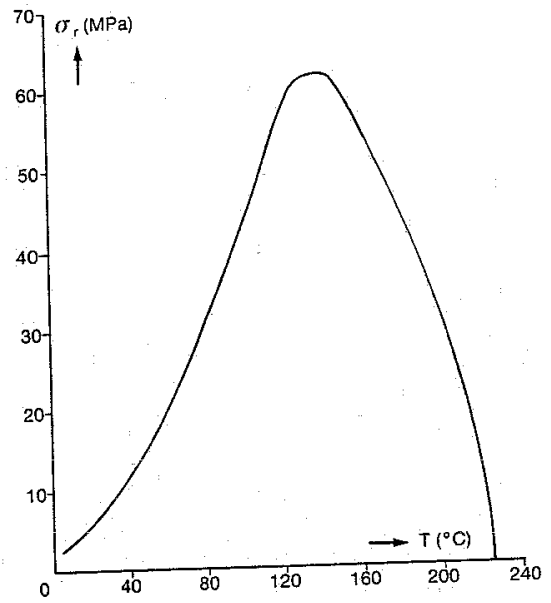

Figure 7. Retractive force measurements of UHMW-PP fibres

In Figure 9 high temperature WAXS patterns are shown of As can be seen in this figure the reflections are sharp indicating that there is a high level of molecular orientation in the fibres. If the UHWW-PP fibres are held at a fixed length during the WAXS experiments a decrease in intensity of the reflections is not observed even after heating for 2 hours at $210^{\circ} \mathrm{C}$. 


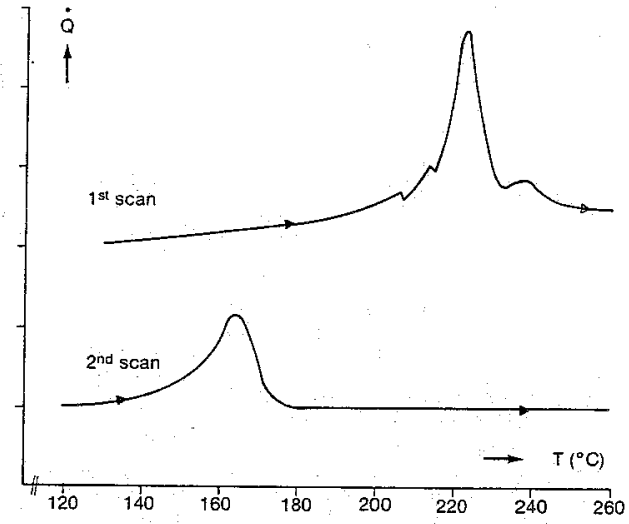

Figure 8. DSC-experiments of constrained UHMW-PP fibres

$\underline{\underline{a}}$

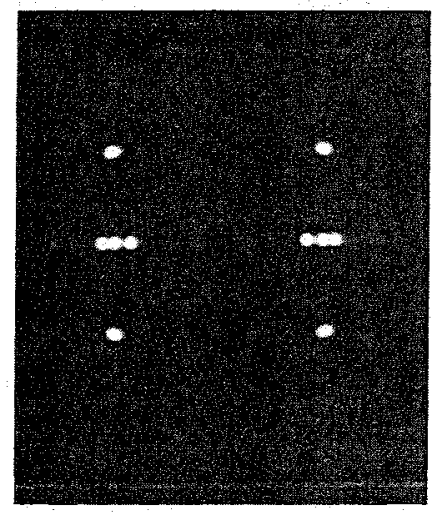

$\underline{\underline{b}}$

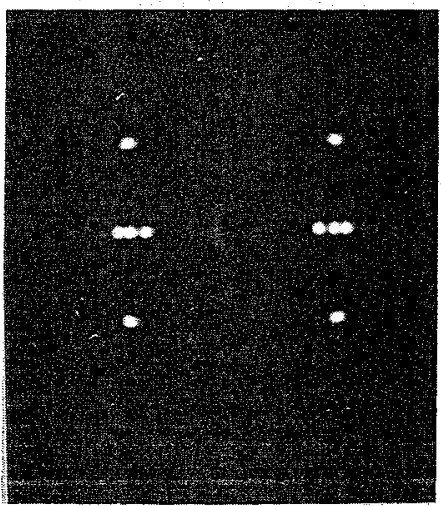

Figure 9. High temperature WAXS patterns of contrained UEMW-PP fibres: a) $180^{\circ} \mathrm{C}$; b) $210^{\circ} \mathrm{C}$ 


\begin{tabular}{cccc}
$\mathbf{T}$ & $t$ & $\begin{array}{l}\mathrm{E}_{23^{\circ} \mathrm{C}} \\
(\mathrm{GPa})\end{array}$ & $\begin{array}{l}\sigma \mathrm{t}_{23}{ }^{\circ} \mathrm{C} \\
(\mathrm{GPa})\end{array}$ \\
\hline- & - & 35 & 1.3 \\
$\left({ }^{\circ} \mathrm{C}\right)$ & 10 & $33-36$ & $1.2-1.4$ \\
180 & 30 & $34-36$ & $1.1-1.3$ \\
180 & 10 & $35-37$ & $1.3-1.4$ \\
200 & 30 & $34-37$ & $1.3-1.4$ \\
\hline
\end{tabular}

Table 2. Young's modulus and tensile strength at room temperature of constrained UHMW-PP fibres as a function of annealing time and temperature

In Table 2 the Young's modulus and tensile strength at room temperature of UHMW-PP fibres are listed as a function of annealing-time and temperature. The UHMW-PP fibres were held at a fixed length during these experiments. As can be seen in Table 2, the UMMW-PP fibres retain their Young's modulus and tensile strength even after heating for 30 minutes at $200^{\circ} \mathrm{C}$. These experimental observations show that UHMW-PP fibre composites can be fabricated and cured at temperatures up to at least $200^{\circ} \mathrm{C}$, without any loss in properties, if the fibre is held at a fixed length during processing/curing.

CONCLLSIONS

絫

The melting behaviour of gelspun/drawn UHMW-PE and UMM-PP fibres can be influenced strongly by imposing constraints. In the case of UHMW-PE fibres, the maximum continuous use temperature is limited due to the orthorombic-hexagonal solid-solid state transition at $155^{\circ} \mathrm{C}$. Above this temperature the chain mobility in the hexagonal phase causes macroscopic failure of the fibre upon annealing and/or stress. In the case of UHMW-PP fibres, effective constraining can be utilized to increase the melting temperature, and consequently the curing and use temperature range is increased significantly. 
REFERENCES

1. Capaccio, G., Crompton, T.A., Ward, I.M., Polymer, 17664 (1976)

2. Zwijnenburg, A., Pennings, A.J., Colloid and Polymer Science, 254, 868 (1976)

3. Southern, J.M., Porter, R.S., J. Appl. Pol. Sci., 14, 2305 (1970)

4. Capaccio, G., Gibson, A.G., Ward, I.M., Ultra-High Modulus Polymers (Eds. A. Ciferri and I.M. Ward), Appl. Sci. Pub, London, Chpt. 1.

5. Lemstra, P.J., Kirschbaun, R., Ohta, T., Yasuda, H., Developments in oriented polymers-2, Editor I.M. Ward, Elsevier Applied Science, I987

6. Matsuo, M. et al., Polymer Journal, 18, 759 (1986)

7. Peguy, A., R. st-John Manly Polymer Com., 25, 39 (1984)

8. Clements, J., Ward, I.M., Polymer, 23, 935 (1982)

9. Smook, J., Ph.. thesis, University of Groningen, The Netherlands, 1984

10. Bassett, P.C., Liquid Crystalline Polyethylene in Polyethylenes 1933-83. Conference issue, Ed. The Plastics and Rubber Institute. London, 1983

11. Van Aerle, N., Lemstra, P.J., to be published

12. Lemstra, P.J., Kirschbaum, R., Polymer Special issue Specialty Polymers, 26, 1372 (1985)

13. Kanamoto, T., Hoshiba, T., Yoshimara, T., Tanaka, K., Takeda, M., Reports on Progress in Polymer Physics in Japan, 28, 227 (1985) 